\title{
The Need for Assessing Knowledge through Writing for the Quality of Education in Post-Soviet Middle-Low Income Countries with an Emphasis on Azerbaijani Context
}

\author{
Heydar Eminli ${ }^{1}$ \\ ${ }^{1} 21$ st Century International Education and Innovation Center, Azerbaijan \\ Correspondence: Heydar Eminli, 21st Century International Education and Innovation Center, Azerbaijan
}

Received: October 17, 2018

Accepted: November 23, 2018

Online Published: February 26, 2019

doi: $10.5539 /$ ies.v $12 \mathrm{n} 3 \mathrm{p} 50$

URL: https://doi.org/10.5539/ies.v12n3p50

\begin{abstract}
Enhancing the quality of education has been placed high in the national policy agenda in Azerbaijan in recent years. Education policy makers are interested in developing quality curriculum for secondary education, implementing teacher development programs and creating a better learning environment. This study outlines one of the most significant skills in education; academic writing, and teaching and assessment of it for the quality in education. The reason for arguing this topic is that a multiple-choice test is still a dominant assessment tool at centralized exams in Azerbaijan, and a student's knowledge cannot be measured through standardized multiple-choice tests only. It is argued that the lack of teaching and learning academic writing at secondary education and its assessment might prevent the student's critical thinking.
\end{abstract}

Keywords: quality in education, teaching writing, assessment, learning, secondary schools, centralized exams

\section{Introduction}

The purpose of this study is in two directions; (1) to explore the current types of assessment as a tool for evaluating learners' knowledge and competence in secondary education and in the university admission process in the developing countries of the post-Soviet bloc, and to examine it more deeply in the case of Azerbaijan, and (2) to attempt to provide some suggestions with regard to the teaching of academic writing in secondary education, based on the relevant previous literature and personal experience. In this article, the field of writing is accepted as one of the key functions of literacy and an important skill for a learner's success at lifelong education.

Obviously, all learners at different stages of education encounter assessment, as assessment is an integral part of education, and defines the quality in education (Kellaghan \& Greaney, 2001; Tikly \& Barrett, 2011; Dawn et al., 2009; Hajiyeva, 2011). According to Tikly (2015), assessment is one of the global and national mechanisms that form education systems and affect teaching and learning. In addition, students who are likely to apply to study at a university are assessed at different ways before starting higher education.

For the enhancement of quality in education, the assessment process itself should be updated and improved by adding the academic writing section to teaching and assessment practices at a national level. As Wolcott and Legg (1998, cited in Blattner, 1999, p. 229) state, writing is strongly combined with the learning process, and the assessment of it forms the core part of 'new educational directions'. I believe this has a strong impact on the quality of education, as this practice covers all educational levels. Therefore, my definition of the 'quality' in education concerns alternative methods of teaching and assessment of literacy to the ones currently used in this region of former Soviet Union, based on Western methods.

\section{Background Literature Review}

The countries of the post-Soviet bloc have gradually updated their education system including the process of transition from secondary education to higher education (Smolentseva, 2012; Koshmanova \& Ravchyna, 2008; Shagdar, 2006; Drummond \& Gabrscek, 2012). Despite the changes, the countries of the region show low performance in the field of education, and providing equal access to high-quality education becomes a serious challenge (Habibov \& Afandi, 2009) that arguably relates to economic factors in these low- and middle-income transitional countries. In general, the countries of the region are faced with similar challenges regarding education quality (DeYoung, 2010; Donabedian \& Carey, 2011; Silova, Johnson \& Heyneman, 2007; Drummond \& 
Gabrscek, 2012), which are strongly related to the economic decline after the countries of the Soviet Union obtained independence (Silova, 2010).

In the case of Azerbaijan, the Ministry of Education has implemented noticeable reforms in terms of curriculum development, teacher education, school management and infrastructure (Secondary Education Sector Development Project, 2010). Meanwhile, the State Exam Centre (SEC), previously, Students Admission Commission (SSAC), that organizes and maintains university entrance exams and other types of state exams which not attached to the Ministry of Education (Drummond \& Gabrscek, 2012) has improved its activities. For the past dozen years, the changes have included organizing, maintaining and governing all types of exams in a centralized and countrywide form, as well as functional part of centralized exams by adding open-ended questions to the test papers in subjects such as mathematics and history in 2011 (SSAC, 2015). It has led to a fairer assessment of students' performance at university entrance exams, getting back the control from individual local universities on making the decision concerning a student's admission. This could otherwise have resulted in illegal earnings (Mustafayev, 2010, cited in Drummond \& Gabrscek, 2012, p. 13).

Regarding the recent statistics, every year about 90,000 students finish secondary schools and about 30,000 of them are admitted to higher education institutions through the centralized exam system in Azerbaijan (SSAC, 2015). Although much effort has been made in the development and modernization of university admission exams in terms of establishing a National Testing Office, improvement of facilities, training of the testing staff, collaboration with international testing companies such as Education Testing Service (ETS) in the USA and gaining public trust in the fairness of providing the exams, the real assessment of knowledge, cognition and competence of young test-takers can be debatable.

In 1992 Azerbaijan was the first among the former Soviet-Union countries to adopt the standardized testing system in a national centralized way (Drummond \& Gabrscek, 2012), and has developed it. But the testing system, which is constructed on multiple-choice assessment, is insufficient for measuring applicants' full knowledge, and it should be improved further, as the national leader and ex-president of the Republic of Azerbaijan, Aliyev (2002) pointed out in his speech at a meeting with the successful applicants with the highest scores at university entrance exams. Based on Biggs' (1988) research on the impact of writing on learning and thinking, it can be appropriate to emphasize that to measure learners' knowledge, essay writing with its all types must be taught in schools, and used in the centralized finals of secondary education and university entrance exams as a way of assessment. As Biggs (1988) contends, an essay task is the most important norm for 'the evaluation of learning'. It stimulates learners' critical thinking ability, and as a result writers do not just think but also become more creative (p. 188). However, Andrews (1968) argues that no test is clear in a perfect way, and the multiple choice and essay sections of the test measure different abilities in a student which cannot be substituted for each other. If the purpose of the centralized exams is to find out whether university applicants are ready to be students at university, it is necessary to consider at least two types of tests during the university admission exams: both essay-type and multiple-choice type versions are necessary for a better evaluation of students' knowledge based on their secondary school level as the contents of these test types are completely different.

In their research article dealing with the quality of education in low-income countries, Tikly and Barrett (2011) point out the importance of providing those skills to people of low-income countries at secondary and further education levels. This is necessary for joining the 'global knowledge economy' (p. 4). DeYoung (2010), in his investigation of Kyrgyz education, stresses the advancement of education as a base for integration into the global market economy. He also points out that the decrease in the quality of secondary education that results in unskilled youth becomes a problem for higher education too.Tikly and Barrett (2011) argue in terms of the insuffiency of the current approaches to meet the key aspects of education quality, including teacher education and training and professional development for teachers, which are all major quality issues identified by Lewin and Stuart (2003), Mattson (2006), Mulkeen (2010), and the UNESCO Insitute for Statistics (2006) (cited in Tikly \& Barrett, 2011, p. 10).

As teaching and assessment are interconnected, the implementation of the teaching of writing across the curriculum and its assessment via state centralized exams could be done in a parallel way. However, the current situation in terms of logistics can make it complicated. One of the problems that some post-Soviet countries, especially those with low-income economies face is the process of transition in the education system (DeYoung, 2010; Whitsel, 2009; Shagdar, 2006; Silova, Johnson \& Heyneman, 2007), which can take time to shape it with regard to quality in education (Habibov \& Afandi, 2009). Another major issue is the financial situations of families that send students to schools (Shagdar, 2006; Whitsel, 2009) and private tutoring (Silova, Johnson \& Heyneman, 2007). Any new educational reform with regard to national curriculum subjects which are related to university entrance exams can cause an additional financial problem for a family (Bray, 2006), and they might not find it 
affordable to hire an additional private tutor to prepare their children for essay writing with a principle focus on university entrance exams. Private tutoring, which has been quite popular since 1990s in post-Soviet countries (Silova, 2010), is aimed at teaching for testing which is focused on solving multiple-choice questions based on the topics of exams in the case of Azerbaijan and other countries of the region.

According to the survey conducted by the Open Society Institute in 2005-2006 (cited in Silova, Johnson \& Heyneman, 2007, p. 172):

'... over 90 percent of surveyed students in Azerbaijan and over 60 percent of surveyed students in Central Asia (Kazakhstan, Kyrgyzstan and Tajikistan) take private tutoring lessons or attend preparatory courses for entering higher education institutions.'

As private tutoring is outside the scope of this research, it is not discussed here.

Quality in education can be approached from different perspectives and it includes certain models, and indicators, depending on the areas of education (Cheong \& Ming, 1997). One of these models identified by Cheong and Ming (1997) is a 'goal and specification model' which is used for the assessment of a learner's academic achievement. Although there are a number of definitions for quality in education from other perspectives too, one of the essential principles for the quality of education, according to United Nations Children's Fund (UNICEF) deals with:

'... outcomes that encompass knowledge, skills and attitudes, and are linked to national goals for education and positive participation in society' (UNICEF, 2000, p. 3).

If this definition lets us draw a conclusion that what is learnt at school is expected to be applied in a real-life context, then these skills should be taught and assessed in an appropriate way for a learner's success. Academic achievement in literacy is one of the core outcomes in education which is defined by assessment for improving learning (UNICEF, 2000). As literacy is considered to be one of the essential goals in formal education (UNICEF, 2000), its teaching and assessment should be implemented by high quality methods, including the skill of essay writing with its all relevant types, which is an inseparable part of literacy.

\section{The Use of Multiple-Choice Tests Compared With Essay-Type Tests, and the Possible Outcomes}

In the case of Azerbaijan and other countries of the post-Socialist bloc, the assessment of learning is carried out by standardized multiple-choice tests (Drummond \& Gabrscek, 2012; Powell, 2007). Although the research conducted on student performance regarding multiple-choice type and essay type exams in different periods (Pepple, Young, \& Carroll, 2010; Blum \& Azencot, 1986) shows that students are more successful in multiple-choice question exams than in essay type exams, Burgin and Hughes (2009) contend that in terms of the limitations of multiple-choice assessment to demonstrate student competence, multiple-choice tests do not provide a deep assessment of learners' knowledge and skills. On the contrary, unlike the multiple-choice tests, the written essay becomes the learner's own product, because while learners think about the topic and respond to it, they develop new ideas (Wolcott \& Legg, 1998 cited in Blattner, 1999, p. 232). Moreover, according to the result of the research conducted by Furnham et al. (2008) in terms of the assessment method favoured by students based on their personality characteristics, surface learners preferred multiple-choice format as an exam type, while deep learners preferred the essay format.

The application of multiple-choice tests was criticized in post-Soviet Russia when the country's admission system called 'Ediniy gosudarstveniy ekzamen' (EGE or Unified State Examination) started using it as a university entrance exam, with the claim that multiple-choice tests cannot adequately assess students' readiness for university, as Drummond and Gabrscek (2012) have reported. Andrews (1968) claims multiple choice tests have greater internal steadiness, however, essay tests may have more reliability on the structure of the questions, as well as the scoring framework which also involves more than one grader to mark an essay. Other research results show that even though students mainly prefer a multiple-choice exam, they also express an interest in an essay exam when they are prepared well for it (Parmenter, 2009).

However, there are some reasons why governments use centralized multiple-choice exams and do not apply essay-type assessment. One of the main reasons, as Linn and Gronlund (2000) (cited in Burgin \& Hughes, 2009, p. 26) assert is that implementing standardized multiple-choice tests is less expensive and takes less time, which can be highly profitable for the low-income transitional countries of the post-Soviet Union. Heyneman (2003) states that the size of the test-taking population affects the costs. Based on his study, we can say that the application of essay-type assignments might be appropriate in Georgia or Kyrgyzstan, however it can be more costly in Uzbekistan or Ukraine with regard to the significant difference of the number of university applicants.

Another reason for not applying an essay-type assessment, according to Huot and Neal (2006) (cited in Burgin \& Hughes, 2009, p. 26) is the problem of reliability due to the incompetence of professionals at scoring essay papers. 
However, after developing rubrics and marking criteria and developing scorers, this problem can be solved.

The third reason for not adopting an essay-type assessment as part of standardized tests probably concerns its subjectivity. In the case of Azerbaijan, the state testing office does its best to protect the fairness of the exam process in all possible ways. However, the issue rests not only on their shoulders, as one of the staff of the SSAC told me, since the tests are based on what is taught in the school curriculum framework. When we familiarize ourselves with the curriculum and subjects separately, as well as the course books, we see that academic and critical writing skills are not taught in schools.

\section{Teaching Before Assessing}

Research by UNICEF (2000) has showed that literacy skills are taught in a language course as a separate subject at schools, and it is suggested that these are incorporated into other subjects in a cross-curriculum way. In order to achieve this alternative way of developing literacy skills through social and science subjects, school teachers should be trained how to teach writing.

While teachers are making progress in teaching children joining the letters and putting the words in the correct order in order to see beautiful and well-formed scripts, it becomes really sad when high school students and first year undergraduates struggle in developing more advanced academic writing. When secondary school graduates start university they integrate into a new academic environment where they will discover more challenging literacy skills, for example, those of critical review, producing an argument and literature research (Krause, 2001). Although in the beginning, student writers have small understanding of these skills, teachers at secondary school are expected to teach them essential essay writing skills, as the Higher Education Council (1992, cited in Krause, 2001, p. 150) asserts,

'.. the essay is a common form of assessment at university and the ability to express oneself competently in a written form is one of the skills most highly prized by employers.'

Training, which is a key quality issue (Tikly \& Barrett, 2011), can be provided for teachers on practicing the design of critical topics for classroom writing assignments as well as developing an analytic system of scoring with rubrics and marking criteria which will help both teachers and students in the teaching and learning process. By understanding the scoring criteria students will be able to produce better and more structured writing and teachers will be more confident in the assessment process. By receiving professional development of the teaching and assessment of writing, teachers will be able to define the assessment system in a better way and be involved in assessment practices in the future (Wolcott \& Legg, 1998 cited in Blattner, 1999, p. 231) that can interweave teaching and centralized testing for students' success before they go to university. The aim is to teach teachers, especially class and language teachers, strategies that they can use to prepare their students for exams with regard to the different styles of writing in different situations. For example, from my informal talk with English teachers at a West Midlands school it was found out that at Key Stages (KS) 3 and 4 at British secondary schools, when pupils reach the age of 13 or 14 they are already taught how to develop writing on various authentic topics such as 'how write a letter or an email to a local council', 'how to write a diary or a recipe', following the structure of the audience, the purpose and the genre. Furthermore, the specifications of the General Certificate of Secondary Education (GCSE) regarding writing are based on clarity, cause and effect and how to write effectively, with a range of forms and styles (Ofqual, 2015), while AS and A-level exams require students to show knowledge and understanding of literary and non-literary topics in a written way by means of critical analysis (GCE AS and A level English language and literature, 2014). These practices can be considered with regard to designing the curriculum with emphasis on writing at secondary schools in Azerbaijan.

A new national curriculum was introduced in Azerbaijan in 2011. However, the evaluation of students' knowledge on taught subjects at the final exams of years 9 and 11 (which is the final year at Azerbaijani secondary education) is conducted by SEC based mainly on multiple-choice questions probably for the reason of making sure that at all secondary schools the exam is conducted in a fair and unbiased way, both so that schools cannot interfere, and it is less costly.

The recent national curriculum of the secondary education in Azerbaijan has been underpinned by Bloom's taxonomy (Kurikulum, 2012), like many other curriculum developments (Ormell, 1974). It is significant that testing and assessment are also associated with the learning process supported by Bloom's taxonomy in order to reach the educational objectives, because in Bloom's taxonomy 'knowledge' as a lower order of thinking skill is followed by categories such as 'comprehension' and 'application' or in a revised taxonomy, 'remembering' as a lower order thinking skill is followed by 'understanding' and 'applying', which are associated with key verbs such as paraphrasing, summarising, interpreting and implementing (Churches, 2009). However, memorizing which is the key aspect of a multiple-choice test is not supported by Bloom's taxonomy. 
My suggestion is that in order to improve quality in education, policy makers should design a curriculum for secondary schools concerning academic writing skills, which can be part of the school subjects, especially in social and humanities pathways. By learning both critical and academic writing, students can also develop critical thinking which is significantly important in higher education. The time management mentioned by Wolcott and Legg (1998), is another important skill that students should be taught with regard to writing (cited in Blattner, 1999, p. 232), so that they are able to use their time more effectively, as students are usually expected to produce their written work in a limited time during language exams (Hill, Storch \& Lynch, 1999). Also, even if students do not plan to pursue higher education, they will have acquired these skills by the time they graduate from secondary schools, so that they can put them into practice in professional life, in terms of writing a personal statement, $\mathrm{CV}$ or résumé for professional purposes in the labour market. In order to achieve this, state institutions responsible for education can explore the experience of other countries which implement it in their teaching and assessment system. In the process of modernization of the curriculum, they are exploring western education models and applying those which can fit to the national curriculum. For example, at secondary schools in Britain students are taught how to develop writing in a systematic and structured way. The topics vary from how to write a letter to a local councilor or how to describe a recipe to more academic genres. The purpose, it seems, is to prepare students not just for universities, but for life. Even some of these students who do not go for higher education will have had some understanding of writing a letter or developing a statement of purpose. From my informal talks with secondary school educators during my school visits in a West Midlands city of England, I learned that the teaching of writing is implemented in a cross-curriculum way, in which, along with English subject, and other subjects, for example, Sociology, History, Literature and Citizenship Studies, students' knowledge is assessed through writing tasks including compositions and essays at different levels from Key Stages 3-4 (KS) and GCSE to A-level exams. Of course, in order to realize this system in the secondary education of the post-Soviet countries, for example in Azerbaijan, some issues, including logistics, the preparation of teaching and testing professionals, and funding of this set of processes can be seen as a challenge (Heyneman, 2003). However, considering the necessity of this activity being incorporated into the secondary education curriculum and later on into the centralized testing which can enhance quality in education and strengthen learning, an educational policy is suggested for implementation of this project.

In the following figure, I make an attempt of describing the stages of incorporating writing into the teaching and assessment process at secondary and higher education; Secondary school teachers receive training on academic writing, and rubrics are developed. Teachers involve students to writing activities, for example, a creative writing and academic writing at high school level as a part of the curriculum and beyond curriculum. The national testing centres integrate essay writing to the centralized exams as a major part of university admission exams.

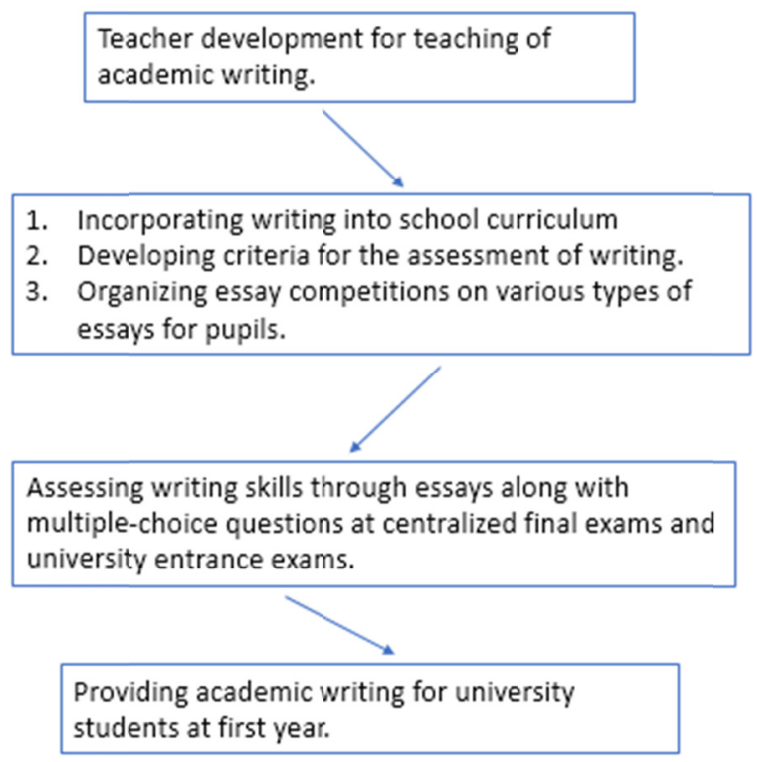

Figure 1. Stages of incorporating writing into the teaching and assessment process 
Considering the impact of this process on the intellectual level of learners, such an initiative should be taken into consideration, and in terms of the realization of this goal the Ministry of Education and the State Exam Centre should collaborate on this matter in order to reach the goal successfully. Although writing is used in the form of compositions at the final exams of the secondary education which are not mandatory to perform but optional, following the multiple-choice tests and the topics are not critical, the teaching of writing academic essays appears, based on my personal observation, not to be supported by the curriculum at Azerbaijani secondary schools. As Wolcott and Legg (1998) (cited in Blattner, 1999, p. 233) point out, learners in these circumstances will not perform well in the exam if they do not practice writing in the classroom. So, in this issue schools and the testing office should work closely together to assess what students have learned in the classroom in terms of writing and how they apply that ability outside the classroom (SAT, 2008).

In recent years a number of Azerbaijani students have been planning and studying abroad, mainly at English-speaking universities (Bohm et al., 2004; State Programme 2007-2015: Education of Azerbaijani youth in foreign countries, 2015). Interestingly, based on my personal observation during my teaching years in secondary education in Azerbaijan, students who have prepared to study abroad, mainly at Western universities had better writing skills in English rather than Azerbaijani, and the reason for this was the preparation for English language proficiency tests, such as the International English Language Testing System (IELTS) exam, internet-based tests of English as a foreign language (iBT TOEFL), the Scholastic Aptitude Test (SAT) and other similar tests. This is because, one of the key conditions for international students who are non-native speakers of English is to take an English proficiency test, mainly either the International English Language Testing System (IELTS) or Test of English as a Foreign Language (TOEFL) test for the university admission especially in English-speaking countries (Brooks \& Waters 2011). When it comes to take either of these tests, students find out that there is a writing section with essay tasks that are required, which characterizes the production of language (Cheng, 2008), for the obvious reason; these tests are a path and a connection to university life where students are going to perform numerous written tasks from an essay to a dissertation. Therefore, before starting the university, students will already have had some understanding of academic writing through preparing for, and taking these tests.

One of the signs of the high quality of education in the education systems of developed countries especially in those who also host the majority of international students including the USA, the UK and Australia (Brooks \& Waters, 2011) is the developed system of academic writing which is an intrinsic part of the education. As Gan (2009) points out, rote learning and memorization, which prevents of developing critical thinking and originality in the learning process, are not appropriate as a learning technique in a Western academia.

\section{Limitations}

The limitation of this study is that it has been examined by doing a literature review and a theoretical approach has been applied. It is possible that a questionnaire survey can be conducted in order to collect data from a target population including secondary and higher education teachers and students, and analyzed so that more detailed results are obtained. Therefore, further research is of paramount importance.

\section{Conclusion}

Admittedly, an essay-type test becomes a problem in terms of unreliability because of the subjective scoring, and students come under time pressure more (Blum \& Azencot, 1986). In addition, in terms of implementing it in a successful way, lack of logistics might be a problem (Heyneman, 2003) that middle-low income countries of the post-Soviet bloc can face. Nevertheless, I am firmly convinced that writing skills and types of essays are extremely suggested to be taught and assessed in addition to multiple-choice tests as applicants taking the centralized university admission exams in Azerbaijan and in other post-Soviet countries encounter writing and its challenges when they enter the university.

It is believed that behind the scene of the quality of education the functional parts such as writing skills are hidden, and these aspects can contribute to the quality of education in terms of a learner's achievement. For example, in the education systems of the developed Western countries, including the UK, the USA and Australia, the teaching and assessment of writing via different types of essays such as academic, discursive and reflective types, play a key role for a learner's success at different levels of secondary and higher education (SAT, 2008; GCE AS and A level English language and literature, 2014; LoCastro \& Masuko, 2002; Gan, 2009). Once students lack the skills of written language, they might make plagiarism in their writing (LoCastro \& Masuko, 2002), which will damage educational integrity.

The issues discussed in this article, based on various previous studies and on my own experience, make the further study of the teaching and assessment of literacy necessary for a learner's real achievement with regard to the significance of the quality of education in the region of the transitional countries of the former Socialist bloc. More 
specifically, integrating academic writing into the learning and assessment will help students develop critical thinking and become more successful and better prepared for academic challenges in their further education and career in a globalized world. Education policy makers, state testing centres and secondary schools can benefit from this article in considering the teaching and assessment of academic writing at a national level.

\section{References}

Aliyev, H. (2002). 2002-ci ildə ali məktəblara yüksək balla qabul olmuş təlabəlarla görüş (meeting with students who scored the highest at university entrance exams in 2002). YouTube, Azerbaijan State Broadcasting Company AzTv, Azerbaijan. Posted by the State Students Admission Commission (SSAC) of the Republic of Azerbaijan.

Andrews, A. S. (1968). Multiple Choice and Essay Tests. Improving College and University Teaching, 16(1), 61-66. https://doi.org/10.1080/00193089.1968.10532703

Biggs, J. (1988). Approaches to Learning and Essay Writing. In R. R. Schmeck (Ed.), Learning Strategies and Learning Styles. Springer. https://doi.org/10.1007/978-1-4899-2118-5_8

Blattner, N. (1999). Demystifying Writing Assessment: Empowering Teachers and Students. Assessing Writing, 6(2), 229-237. https://doi.org/10.1016/S1075-2935(00)00011-8

Blum, A., \& Azencot, M. (1986). Multiple-choice versus equivalent essay questions in a national examination. European Journal of Science Education, 8(2), 225-228. https://doi.org/10.1080/0140528860080210

Bohm, A., Follari, M., Hewett, A., Jones, S., Kemp, N., Meares, D., ... Van Cauter, K. (2004). Forecasting international student mobility: A UK perspective. London: British Council.

Bray, M. (2006). Private supplementary tutoring: comparative perspectives on patterns and implications. Compare: A Journal of Comparative and International Education, 36(4), 515-530. https://doi.org/10.1080/03057920601024974

Brooks, R., \& Waters, J. (2011). Student Mobilities, Migration, and the Internationalization of Higher Education. Palgrave Macmillan. https://doi.org/10.1057/9780230305588

Burgin, J., \& Hughes, G. D. (2009). Credibly assessing reading and writing abilities for both elementary student and program assessment. Assessing Writing, 14, 25-37. https://doi.org/10.1016/j.asw.2008.12.001

Cheng, L. (2008). Washback, impact and consequences. In N. H. Hornberger (Ed.), Encyclopedia of language and education. Springer, US. https://doi.org/10.1007/978-0-387-30424-3_186

Cheong, C. Y., \& Ming, T. W. (1997). Multi-models of quality in education. Quality Assurance in Education, 5(1), 22-31. https://doi.org/10.1108/09684889710156558

Churches, A. (2009). Bloom's digital taxonomy (pp. 1-44).

Dawn, P., Ross, B., Peter, H., \& Lorna, G. (2009). Curriculum, pedagogy and assessment: three message systems of schooling and dimensions of quality physical education. Sport, Education and Society, 14(4), 421-442. https://doi.org/10.1080/13573320903217125

DeYoung, A. J. (2010). Embracing globalization: university experiences among youth in contemporary Kyrgyzstan. Central Asian Survey, 29(4), 421-434. https://doi.org/10.1080/02634937.2010.535312

Donabedian, D. A., \& Carey, J. (2011). Open Access and Liberal Education: A Look at Armenia, Azerbaijan, and Georgia. Slavic \& East European Information Resources, 12(4), 201-223. https://doi.org/10.1080/15228886.2011.621113

Drummond, T. W., \& Gabrscek, S. (2012). Understanding Higher Education Admissions Reforms in the Eurasian Context. European Education, 44(1), 7-26. https://doi.org/10.2753/EUE1056-4934440101

Furnham, A., Christopher, A., Garwood, J., \& Martin, N. G. (2008). Ability, demography, learning style, and personality trait correlates of student preference for assessment method. Educational Psychology, 28(1), 15-27. https://doi.org/10.1080/01443410701369138

Gan, A. (2009). Chinese students' adjustment to the International Baccalaureate Diploma Programme. Journal of Research in International Education, 8(3), 283-304. https://doi.org/10.1177/1475240909345815

GCE AS and A level English language and literature. (2014). Retrieved from https://www.gov.uk/government/publications/gce-as-and-a-level-for-english-language-and-literature

Habibov, N. N., \& Afandi, E. (2009). Analysis of subjective wellbeing in low-income transitional countries: 
evidence from comparative national surveys in Armenia, Azerbaijan and Georgia. Journal of Comparative Social Welfare, 25(3), 203-219. https://doi.org/10.1080/17486830903189956

Hajiyeva, T. (2011). Monitorinq, qiymetlendirme ve tehsilin keyfiyyeti (Monitoring, assessment and quality of education). Retrieved from http://www.muallim.edu.az/arxiv/2011/11/20.htm

Heyneman, S. (2003). Misconduct in education. In Encyclopedia of Education. MacMillan, New York.

Hill, K., Storch, N., \& Lynch, B. (1999). A Comparison of IELTS and TOEFL as Predictors of Academic Success. Research. The University of Melbourne, IELTS Australia.

Kellaghan, T., \& Greaney, V. (2001). Using assessment to improve the quality of education. UNESCO: International Institute for Educational Planning.

Koshmanova, T., \& Ravchyna, T. (2008). Teacher preparation in a post-totalitarian society: an interpretation of Ukrainian teacher educators' stereotypes. International Journal of Qualitative Studies in Education, 21(2), pp. 137-158. https://doi.org/10.1080/09518390701256415

Krause, K.-L. (2001). The University Essay Writing Experience: A pathway for academic integration during transition. Higher Education Research \& Development, 20(2), 147-168. https://doi.org/10.1080/07294360123586

Kurikulum. (2012). Training program. Retrieved from http://www.kurikulum.az/index.php/az/resurslar/t-limproqramlar

LoCastro, V., \& Masuko, M. (2002). Plagiarism and Academic Writing of Learners of English. Journal of Linguistics, 28.

Office of Qualifications and Examinations. (2015). GCSE subject criteria for English. Retrieved from https://www.gov.uk/government/publications/gcse-subject-criteria-for-english

Ormell, C. P. (1974). Bloom's Taxonomy and the Objectives of Education. Educational Research, 17(1), 3-18. https://doi.org/10.1080/0013188740170101

Parmenter, D. A. (2009). Essay versus Multiple-Choice: Student preferences and the underlying rationale with implications for test constructions. Academy of Educational Leadership Journal, 13(2), 57-71.

Pepple, D. J., Young, L. E., \& Carroll, R. G. (2010). A comparison of student performance in multiple-choice and long essay questions in the MBBS stage I physiology examination at the Universityof the West Indies (Mona Campus). Advances in Physiology of Education, 34, 86-89. https://doi.org/10.1152/advan.00087.2009

Powell, S. (2007) Developments in Central Asian Higher Education. Retrieved from http://wenr.wes.org/2007/06 /wenr-june-2007-feature

SAT. (2008). Writing Section. Retrieved from https://professionals.collegeboard.com/testing/sat-reasoning/about/ sections/writing

Secondary Education Sector Development Project. (2010). Retrieved from http://edu.gov.az/en/page/84/2501

Shagdar, B. (2006). Human capital in Central Asia: trends and challenges in education. Central Asian Survey, 25(4), 515-532. https://doi.org/10.1080/02634930701210609

Silova, I. (2010). Private tutoring in Eastern Europe and Central Asia: policy choices and implications. Compare: A Journal of Comparative and International Education, 40(3), 327-344. https://doi.org/10.1080/03057920903361926

Silova, I., Johnson, M. S., \& Heyneman, S. P. (2007). Education and the Crisis of Social Cohesion in Azerbaijan and Central Asia. Comparative Education Review, 51(2), 159-180. https://doi.org/10.1086/512022

Smolentseva, A. (2012). Access to Higher Education in the Post-Soviet States: Between Soviet Legacy and Global Challenges. Paper commissioned and presented at Global Seminar, Session, Salzburg. Retrieved from https://www.salzburgglobal.org/fileadmin/user_upload/Documents/2010-2019/2012/495/Session_ Document_AccesstoHigherEducation_495.pdf

SSAC. (2015). Digest of Education Statistics in Testing and Admissions. State Students Admission Commission (SSAC), Baku.

State Programme 2007-2015: Education of Azerbaijani youth in foreign countries. (2015). Xaricde Tehsil (Study Abroad). Ministry of Education of the Republic of Azerbaijan. 
Tikly, L. (2015). What works, for whom, and in what circumstances? Towards a critical realist understanding of learning in international and comparative education. International Journal of Educational Development, 40, 237-249. https://doi.org/10.1016/j.ijedudev.2014.11.008

Tikly, L., \& Barrett, A. M. (2011). Social justice, capabilities and the quality of education in low income countries. International Journal of Educational Development, 31, 3-14. https://doi.org/10.1016/j.ijedudev.2010.06.001

UNICEF. (2000). Defining Quality in Education. Education, United Nations Children's Fund, New York.

Whitsel, C. M. (2009). Family resources, sitting at home and democratic choice: investigating determinants of educational attainment in post-Soviet Tajikistan. Central Asian Survey, 28(1), 29-41. https://doi.org/10.1080/02634930902771516

\section{Copyrights}

Copyright for this article is retained by the author(s), with first publication rights granted to the journal.

This is an open-access article distributed under the terms and conditions of the Creative Commons Attribution license (http://creativecommons.org/licenses/by/4.0/). 